Artykuly / Articles

Małgorzata Gałęziowska

ORCID: 0000-0002-4255-260X

gosia.galeziowska@wp.pl

Muzeum Warmii i Mazur w Olsztynie

Dział Historii i Etnografii

\title{
Bezpieczna tożsamość. Cele aktywności organizacyjnej mniejszości niemieckiej na Warmii i Mazurach
}

\author{
Safe identity. Purposes of organisation activity \\ of the German minority in Varmia and Masuria
}

DOI: 10.34739/doc.2020.17.05

\begin{abstract}
Abstrakt: Celem artykułu jest charakterystyka bezpiecznej tożsamości narodowej członków stowarzyszeń mniejszości niemieckiej na Warmii i Mazurach jako wytworu celowych działań tych stowarzyszeń. Bezpieczna tożsamość jest definiowana jako niekonfliktowa tożsamość narodowa, odpowiednia w warunkach złożonej przeszłości regionu. Powstaje ona w rezultacie bezpośrednich i pośrednich relacji komunikacyjnych i rzeczowych w stowarzyszeniach, jest podtrzymywana poprzez kontakty $z$ organizacjami niemieckimi. Charakterystyka bezpiecznej tożsamości jest rezultatem analizy działalności stowarzyszeń mniejszości niemieckiej, zadeklarowanej w statutach i opisanej w czasopismach stowarzyszeń. W analizie treści uwzględniono wskazania na cechy kontaktów pośrednich i bezpośrednich, cechy przeszłości służące do kształtowania tożsamości oraz najważniejsze obszary działalności stowarzyszeń.
\end{abstract}

Słowa kluczowe: mniejszość niemiecka, Warmia i Mazury, tożsamość, aktywność organizacyjna

Abstract: The aim of the article is to characterize a safe national identity created by associations of the German minority in Varmia and Masuria. The safe identity is defined as a non-conflicting national identity, appropriate to the conditions of the region's complex history. It arises as a result of direct and indirect communication and material relations in associations. The characteristics of a safe identity are the result of an analysis of the real activities of the German minority associations, declared in the statutes and described in the 
associations' newspapers. The content analysis included indications of the features of direct and indirect contacts, features of the past used to shape identity and the most important areas of association activity.

Keywords: the German minority, Varmia and Masuria, identity, organisational activity

\section{Wprowadzenie}

Bezpieczna tożsamość oznacza powszechnie taki stan, w którym dane osobowe i jakiekolwiek informacje identyfikujące człowieka nie są kradzione, nie sa przedmiotem handlu albo też nie stanowią dla niego zagrożenia. Należy rozumieć więc, że to oznacza identyfikację niepowodująca konfliktów w otoczeniu społecznym i w komunikacji publicznej. Tożsamość jest definiowana jako wielowarstwowe poczucie siebie, zakorzenione w przeszłości i teraźniejszości własnej rodziny, zawodu, miejsca pracy, kręgu znajomych i przyjaciół, wyznania, przekonań społecznych i politycznych, a także przynależności do organizacji państwowej i wspólnoty narodowej ${ }^{1}$. Taka tożsamość może być opisywana w kategorii zagrażającej, bezpiecznej, neutralnej, jeśli zostanie zestawiona $z$ mniej czy bardziej przewidywalnymi rezultatami jej publicznego eksponowania. Tożsamość osobowa ma procesualny charakter, jest weryfikowana w teraźniejszości, w odniesieniu do przeszłości z perspektywa na przyszłość, dlatego jej potencjalna konfliktowość nie jest stała. Obraz tożsamości, która jest kształtowana jako tożsamość bezpieczna, zostanie pokazany na przykładzie działalności stowarzyszeń mniejszości niemieckiej na Warmii i Mazurach. Zakres i rodzaje aktywności organizacji mniejszości niemieckiej na Warmii i Mazurach, wynikajacych z zadań statutowych, wskazują następujące, zasadnicze ukierunkowanie: kształtowanie niemieckiej tożsamości narodowej. W lokalnych warunkach to zadanie jest realizowane poprzez relacje międzyosobowe, dla których najważniejsze wydają się: 1) spotkania w swoim gronie; 2) wspomnienia przeszłości; 3) wsparcie materialne

${ }^{1}$ M. Golka, Czy istnieje wielokulturowość tożsamości?, [w:] Kim jestem? Kim jesteśmy? Antropologiczne $i$ socjologiczne konteksty współczesnej tożsamości, red. D. Czakon i M. Boruta, przy współp. R. Hołdy i R. Kantora, Kraków 2012, s. 11-12, 18-19. 
i możliwość działania w tej kwestii. Badaniu poddane zostały treści statutów organizacji mniejszości niemieckiej, struktura organizacyjna, publikacje prasowe, przegląd stałych aktywności. Celem analizy była próba weryfikacji założenia o kształtowaniu bezpiecznej tożsamości, rozumianej jako stabilna autoidentyfikacja w złożonym, polsko-niemiecko-wschodnioprusko-mazursko-warmińskim układzie kulturowym i narodowym.

\section{Identyfikacja regionalna}

Ukształtowana do połowy XX w. typologia narodowościowa mieszkańców Prus Wschodnich jako części państwa niemieckiego to rezultat zróżnicowania językowego, kulturowego. Jest ona zwiąana ze świadomością przynależności do grupy etnicznej i narodowej. Obejmowała zasadniczo Niemców oraz ludność używająca gwary i zwyczajów warmińskich i mazurskich, języka polskiego i świadomych zwiąków $z$ narodem polskim² ${ }^{2}$. Typologia ta opisywała identyfikację etniczna i narodowa społeczności regionalnej, w jej wspólnotowej, środowiskowej i grupowej postaci. Nasilający się proces instytucjonalizacji sfery publicznej sprawił, że ludność identyfikująca się z Niemcami, czyli mniejszość niemiecka w Polsce, przyjęła trwała zorganizowana formę. $Z$ rozmaitych względów na Warmii i Mazurach dokonało się to dopiero pod koniec lat 80. XX w., gdy np. na Śląsku stało się to dużo wcześniej ${ }^{3}$. Ten stan rzeczy wiąze się $z$ masowa migracją do Niemiec mieszkańców przedwojennych Prus Wschodnich czyli ludności niemieckiej, warmińskiej, mazurskiej i polskiej - po 1945 r. Migracje zostały wymuszone - najpierw w rezultacie postanowień traktatu pokojowego, następnie jako pokłosie decyzji administracyjnych w Polsce. Każdy mieszkaniec dawnych Prus Wschodnich musiał podjąć decyzję o przynależności państwowej, co w Polskiej Rzeczpospolitej Ludowej oznaczało wyjazd do Niemiec lub pozostanie w kraju. W kolejnych latach po II wojnie światowej te decyzje determinowały względy rodzinne - były to kolejne odsłony akcji „łączenia rodzin” w Niemczech i w Polsce - względy ekonomiczne,

\footnotetext{
2 A. Sakson, Mazurzy - dylematy tożsamości, „Rocznik Ziem Zachodnich”, 01/2017, s. 41-44; B. Domagała, Mniejszość niemiecka na Warmii i Mazurach. Rodowód kulturowy, organizacja, tożsamość, Olsztyn 1996, s. 117-118; P. Madajczyk, Niemcy polscy 1944-1989, Warszawa 2001, s. 11.

3 P. Madajczyk, Niemcy polscy..., s. 11-12.
} 
a także indywidualne rozczarowania związane $z$ poziomem życia w PRL4.

Demokratyzacja systemu politycznego w Polsce, na przełomie lat 80. i 90., przyczyniła się nie tylko do usunięcia wszelkich formalnych barier dotyczących funkcjonowania mniejszości. Jednocześnie nastapiła również istotna zmiana społeczna zwiazana $z$ otwartościa na wielokulturowość. Jak stwierdzaja Adam Bobryk i Cezary Kalita „Wzrost akceptacji różnorodności narodowej przyczyniał się do ograniczania napięć i negatywnych zjawisk związanych $z$ przynależnością narodowa. Pozytywne oddziaływanie na te przemiany miała demokratyzacja systemu społecznego, otwarcie granic, swobodne przemieszczanie się ludzi między poszczególnymi państwami na kontynencie europejskim, nieograniczony dostęp do wytworów kultury, ukazywanie różnorodności jako pewnej wartości, a nie zagrożenia"5. Ci mieszkańcy dawnych Prus Wschodnich, którzy pozostali w Polsce, w sposób całkowicie swobodny zdecydowali w tych warunkach o organizacyjnej formie kształtowania tożsamości niemieckiej6. Powstało wówczas kilkadziesiąt organizacji, skoncentrowanych w dawnych, wschodniopruskich miastach powiatowych, niejako w odpowiedzi na strukturę organizacji ziomkowskich, funkcjonującą w Niemczech od połowy XX w. oraz na przykładzie Niemieckich Kół Przyjaźni (Deutsche

4 A. Sakson, Mazurzy - społeczność pogranicza, Instytut Zachodni, Poznań 1990, s. 162-165, 200-202; idem, Stosunki narodowościowe na Warmii i Mazurach 1945-1997, Poznań 1998, s. 245-248.

5 A. Bobryk, C. Kalita, Policy and the national minorities in Poland. Social and philosophical aspect, „Austrian Journal of Humanities and Social Sciences” 2015, nr 11-12, s. 75.

${ }^{6}$ H. Mamzer, Poczucie bezpieczeństwa ontologicznego. Uwarunkowania społecznokulturowe, „Seria Socjologia”, nr 58, Poznań 2008, s. 26; Cf. np. (lek), Heidemühle. 15. Geburtstag der Gesellschaft. Jubiläum mit Flammen/Borowy Młyn. Piętnaste urodziny stowarzyszenia. Jubileusz z płomieniami, „Mitteilungsblatt” 2009, nr 9, s. 7. Symbolicznym początkiem zmiany polityki władz wobec mniejszości było zniesienie 7 kwietnia 1989 r. ograniczenia, iż dana społeczność narodowa może posiadać tylko jedna organizację. Zainicjowany dialog sprzyjał aktywizacji środowisk mniejszościowych, a modyfikacja prawa, szczególnie w zakresie wdrożenia Ustawy z 6 stycznia 2005 r. o mniejszościach narodowych i etnicznych oraz o języku regionalnym, tworzyła warunki do swobodnego rozwoju, umacniania tożsamości i szerokiego uczestnictwa w życiu społecznym. A. Bobryk, Attitudes towards the Mother Tongue as an Identity Manifestation of National and Ethnic Minorities in Poland, [w:] Identities of Central-Eastern European Nations, red. V. Yevtukh, A. Wysocki, G. Kisla, A. Jekaterynczuk, Kyiv 2016, s. 179-181. 
Freundschaftskreise - DFK), istniejacych od 1988 r. na Ślasku7. Organizacje te zastrzegały w statutach, że skupiaja zasadniczo ludność „pochodzenia niemieckiego", aczkolwiek jedno $z$ nich zapraszało tych, którzy identyfikowali się jako Mazurzy. Od połowy lat 90. strukturę części stowarzyszeń scala „organizacja dachowa” - Związek Stowarzyszeń Niemieckich na Warmii i Mazurach (ZSNWM) - forma skupiająca prawie wszystkie istniejące $\mathrm{w}$ regionie stowarzyszenia mniejszości niemieckiej. Nie należą do niej: Olsztyńskie Stowarzyszenie Mniejszości Niemieckiej w Olsztynie (OSMN), organizacja w Nidzicy, Stowarzyszenie Mazurskie oraz Warmińsko-Mazurski Związek Kobiet ${ }^{8}$. Strukturalna dwoistość nie wynika prawdopodobnie ze zróżnicowania celów działania, a ze sposobu i form ich osiagania oraz - prawdopodobnie $z$ powodów personalnych ${ }^{9}$. Organizacje mniejszości niemieckiej na Warmii i Mazurach nie sa zbyt liczne, większość $z$ nich została założona przez wasskie grono aktywnych osób, pozostających w relacjach rodzinnych, sąsiedzkich, przyjaźni i znajomości, dla których podstawą działania było miejsce urodzenia, pamięć o przeszłości i przekonania na temat własnej, niemieckiej identyfikacji narodowej. $Z$ biegiem lat zmniejszyła się zarówno liczba stowarzyszeń, jak i ich liczebność.

Członkowie stowarzyszeń mniejszości niemieckiej na Warmii i Mazurach uczestniczą w kulturze polskiej i niemieckiej czy też kulturze polskiej i warmińskiej lub mazurskiej. Nie jest to uczestnictwo równomierne, na co wskazuje np. obecnie słaba znajomość języka niemieckiego. Przestrzenne rozproszenie członków stowarzyszeń, małżeństwa mieszane, brak praktyki kulturowej i ukrywanie niemieckich korzeni przez lata potęgowały ich asymilację w polskiej kulturze ${ }^{10}$. Podtrzymywaniu niemieckiej tożsamości narodowej nie sprzyjały wspomnienia o niemieckich zbrodniach podczas II wojny światowej i układ polityczny po jej zakończeniu, a także cechy tożsamości lokalnej mieszkańców Prus Wschodnich - współistnienie polskości,

\footnotetext{
710 Jahre Deutsche Gesellschaften im Gebiet Ermland und Masuren. Eine Chronik, Verband der deutschen Gesellschaften im ehem. Ostpreußen, Text und Zusammenstellung Elisabeth Kallenbach, Allenstein 2000, s. 9; B. Domagała, Mniejszość niemiecka na Warmii i Mazurach..., s. 116; A. Sakson, Stosunki..., s. 331.

8 Cf. wykaz organizacji należących i nienależacych do Zwiąku Stowarzyszeń Niemieckich Warmii i Mazur, https://www.zsnwim.eu/pl/, (data dostępu: 17.11.2020). 9 A. Czesla, 15 lat Zwiazku Niemców na Warmii i Mazurach, „Mitteilungsblatt”, nr 4/2008, s. 4.

10 Cf. A. Sakson, Rola mniejszości niemieckiej w stosunkach polsko-niemieckich na przykładzie Warmii i Mazur, „Przegląd Zachodni” 1998, z. 11, s. 4.
} 
warmińskości i mazurskości, znaczny udział języka polskiego i gwar w kształtowaniu lokalnej kultury przed 1945 r. Do cech lokalnej tożsamości, zarówno przed II wojna światowa, jak i po jej zakończeniu, można próbować zaliczyć nieustanne poczucie zagrożenia, związane z używanym - polskim i niemieckim - językiem, zwyczajami - polskimi, niemieckimi, warmińskimi, mazurskimi czy przekonaniami politycznymi, a także $z$ pewnym wyalienowaniem społecznym ${ }^{11}$. Dlatego też bezpieczna tożsamość, która oferują stowarzyszenia mniejszości niemieckiej swoim członkom jest bardzo atrakcyjna. Jej kształt wyłania się, jak się wydaje, $z$ idei komunitaryzmu, podkreślających rolę więzi i relacji wspólnotowych ${ }^{12}$. Bezpieczna tożsamość tworzy się poprzez rozmaite aktywności, których zadaniem jest odtwarzanie, podtrzymywanie i kształtowanie takiej niemieckiej tożsamości osobowej, która nie zagraża codziennemu funkcjonowaniu w polskim środowisku kulturowym, a jednocześnie daje pożądane i zgodne $z$ osobistymi losami poczucie odrębności.

Aktywności realizowane przez organizacje mniejszości niemieckiej można poddać próbie systematyzacji - są one ukierunkowane wewnętrznie i zewnętrznie ${ }^{13}$. Aktywności skierowane na zewnątrz zostały tu zasadniczo pominięte, chociaż część aktywności wewnętrznych i zewnętrznych trudno precyzyjnie rozdzielić. Wśród aktywności wewnętrznych wyodrębniaja się te, które można uznać za zabezpieczające tożsamość oraz te, które działaja wspomagająco - zabezpieczaja przynależność do grupy i zabezpieczają byt.

\section{Spotkania w swoim gronie - zabezpieczenie autoidentyfikacji}

Aktywności zabezpieczające tożsamość członków organizacji mniejszości niemieckiej są bardzo różnorodne i nieco zmieniaja się w czasie. Początkowo szczególnie ważne wydawały się zwyczajne, regularne spotkania - przy kawie i cieście - podczas których wzmacniały

11 E.C. Król, Polska i Polacy $w$ propagandzie narodowego socjalizmu $w$ Niemczech 1919-1945, Warszawa 2006, s. 52-53, 62-64; A. Sakson, Mazurzy..., s. 77-79.

12 A. Gawkowska, Aktywne społeczeństwo a komunitaryzm według Amitaia Etzioniego, [w:] A. Etzioni, Aktywne społeczeństwo. Teoria procesów społecznych i politycznych, przeł. S. Burdziej, Nomos, Kraków 2012, s. VIII-IX.

13 M. Gałęziowska, Tożsamość organizacyjna mniejszości niemieckiej na Warmii i Mazurach, Olsztyn 2017, s. 179-180. 
się więzi, rosło nadszarpnięte przez lata zaufanie ${ }^{14}$. Dość szybko członkowie mniejszości zaczęli się spotykać w większych grupach, na dorocznych letnich festynach. Pierwsze Sommerfeste zostało zorganizowane 27 lipca 1991 r. w Najdymowie, w gospodarstwie Paula Gollana, przewodniczącego Społeczno-Kulturalnego Stowarzyszenia Mniejszości Niemieckiej na Warmii i Mazurach $z$ siedziba $\mathrm{w}$ Biskupcu $^{15}$. Następne było w Ostródzie, a kolejne zwoływano co dwa lata, najczęściej w Muzeum Budownictwa Ludowego w Olsztynku16. Podczas festynów poznawali się ludzie ze wszystkich organizacji $\mathrm{w}$ regionie, zaproszeni goście $z$ Landsmannschaft Ostpreussen $i$ innych niemieckich związów. Odrębną formą spotkań były letnie spotkania Mazurów w rodzinnych stronach, które Stowarzyszenie Mazurskie organizowało w Krutyni, Sorkwitach, Karwinach ${ }^{17}$. Od połowy lat 90. okazjonalnie spotykali się seniorzy - na wielkie spotkanie do Starych Jabłonek koło Olsztyna 14 grudnia 1995 r. przyjechało ponad 200 osób ze wszystkich stowarzyszeń ${ }^{18}$. Podobne spotkanie miało miejsce 22 września 1996 r., w Hotelu Gołębiewski w Mikołajkach, gdzie przyjechało 230 osób ${ }^{19}$. W kolejnych latach organizowano podobne spotkania seniorów mniejszości niemieckiej20. Ważną częścią tradycji niemieckiej są spotkania adwentowe, a także nabożeństwa katolickie w języku niemieckim, aczkolwiek regularnie sa odprawiane chyba tylko w Olsztynie, w kościele pw. Bogarodzicy

\footnotetext{
14 Cf. informacje o spotkaniach członków stowarzyszeń oraz spotkaniach kółek zainteresowań, np. robótek ręcznych, chórów, spotkania organizacyjne: „Osteroder Rundbrief” nr 3(15), III 1993; „Mitteilungsblatt” nr 6(21) VII 1996; (lek), Osterode. Ein Netz, das verbindet, aber nicht fesselt. Gemeinsam geht mehr, ibidem, nr 10(254), 2016, s. 6.

1510 Jahre Deutsche Gesellschaften im Gebiet Ermland und Masuren. Eine Chronik., s. 110.

16 Informacje i sprawozdania $z$ przebiegu kolejnych Sommerferste sa umieszczone w: „Osteroder Rundbrief” nr 8, VIII 1992; „Mitteilungsblatt” nr 7(13) VIII-IX 1995, s. 4-5; nr 6(50), VII 1999, s. 12.

17 Cf. np.: Sommetreffen in Siegsmundhof, „Masurische Storchenpost” nr 1/1991, s. 2; J. Lisowski, Eröffnung des Sommertreffens, ibidem, nr 8/1993, s. 3-4; Sommetreffen in Masuren. 3-10 Juli in Kruttinnen/Krutyń, ibidem, nr 6/1994, s. 4-7.

18 (is), Großes Seniorentreffen in Stare Jabłonki, „Mitteilungsblatt” nr 1(16), I 1996, s. 2.

19 [Program spotkania seniorów], „Mitteilungsblatt” nr 9(24), X 1996, s. 10.

20 Cf. np.: [Weinachtstreffen in der AGDM], „Mitteilungsblatt” nr 1(16) I 1996, s. 6; ibidem, nr 2(38), III-IV 1998, s. and Wiener Waltzen. Spotkanie seniorów z Stuttgarten Saloniker w Olsztynie, ibidem, nr 9(53), X 1999, s. 1 i 2.
} 
Dziewicy Matki Kościoła21. Przez jakiś czas członkowie mniejszości organizowali też bale karnawałowe ${ }^{22}$. Do tradycji należy zaliczyć regularne publikowanie w prasie stowarzyszeń życzeń urodzinowych dla członków-jubilatów 23 .

Prasa należała do najważniejszych pośrednich narzędzi kształtowania tożsamości w organizacjach mniejszości niemieckiej niemal od poczattku ich funkcjonowania. Były to rozmaite periodyki, rozprowadzane początkowo w najróżniejszej jakości - w formie odbitek ksero, ale i w postaci bardzo przyzwoitego druku gazetowego. Do dziś istnieje „Mitteilungsblatt” oraz „Allensteiner Nachrichten” w wersji elektronicznej i papierowej24 Zasadniczo sa to periodyki niemieckojęzyczne, ale część artykułów jest publikowana po polsku. Wiąże się to $z$ niezbyt powszechną znajomością języka niemieckiego wśród członków stowarzyszeń mniejszości niemieckiej. Po zakończeniu II wojny światowej na Warmii i Mazurach społeczność rodzima $z$ oczywistych powodów ukrywała jego znajomość, w trosce o dzieci nie przekazywała im tej umiejętności, więc obecni członkowie stowarzyszeń mniejszości rzadko ją posiadają ${ }^{25}$. Stowarzyszenia starają się dotrzeć ze swoja informacja i publicystyka także do tych, których zniechęca brak możliwości komunikacji w wybranym języku.

21 [Ogłoszenia o Adventssontag und Adventstreffen], „Osteroder Rundbrief” nr 9 IX 1992, ibidem, nr 11(23) XI 1993; Weinachtsfeier in der deutschen Volksgruppe Deutsch Eylau, „Mitteilungsblatt” nr 1(16), I 1996, s. 2.; cf. np. godzinowy wykaz Katholische Gottesdienste in Dezember, "Allensteiner Nachrichten” nr 1/2003, s. 6; Katholische Gottesdienste im Juli, ibidem, nr 6 (104), 24 VI 2012, s. 5; Cf. informacje o nabożeństwach i mszach świętych: https://www.agdm.pl/ de/aktuelles-vonder-agdm/aenderung-der-deutschsprachigen-gottesdienstzeiten/, (data dostępu: 18.11.2020).

22 Cf. np. ogłoszenia i relacje $z$ kolejnych bali karnawałowych: „Mitteilungsblatt” nr 1(16), I 1996 s. 5; ibidem, nr 3(30), III 1997; ibidem, nr 1(45), I 1999, s. 12.

$23 \mathrm{~W}$ prasie publikowane sa wykazy imion, nazwisk i rocznicy urodzin, w kolumnie Geburtstagsglückwünsche, cf. np.: „Mitteilungsblatt” nr 9(157), 2008, s. 18; ibidem, nr 3(187) 2011, s. 18; ibidem, nr 3(223) 2014, s. 18; ibidem, nr 3(247) 2016, s. 18 ; ibidem, nr 3(283) 2019, s. 18.

24 Numery czasopism sa dostępne na stronach organizacji: https:// www.zsnwim.eu/pl/miesiecznik; https://www.agdm.pl/projekty/allensteiner-nachrichten/, (data dostępu: 17.11.2020).

${ }_{25}$ Po zakończeniu wojny język niemiecki w każdej postaci był likwidowany w przestrzeni publicznej, na łamach lokalnej prasy oskarżano autochtonów o posługiwanie się nim w miejscach publicznych: „Wiadomości Mazurskie” nr 284, 8 XII 1946, s. 2; ibidem, nr 104, 7 V 1946, s. 4; „Życie Olsztyńskie” nr 153, 5 VI 1948, s. 3. 
Dlatego też statutowa działalność organizacji obejmuje nauczanie języka niemieckiego, jako że jego znajomość jest jednym $z$ wyznaczników przynależności do kultury, do narodu ${ }^{26}$. $Z$ biegiem lat ta działalność skierowana jest w coraz szerszym stopniu na społeczność lokalną, a nie tylko na samych członków mniejszości niemieckiej27. Znajomość obcego języka jest zwyczajnie przydatna - Warmia i Mazury są chętnie odwiedzane przez Niemców w ramach tzw. „turystyki sentymentalnej", a wysokie bezrobocie zmusza do wyjazdów zarobkowych, także do Niemiec ${ }^{28}$.

\section{Wspomnienia przeszłości - zabezpieczenie przynależności}

Do aktywności zabezpieczajacych tożsamość członków organizacji mniejszości niemieckiej należy popularyzacja niemieckiej historii regionu. Obejmuje ona wypowiadanie krzywd, wątki, które odkrywają nieszczęścia i cierpienia mieszkańców Prus Wschodnich, jakich doznawali oni od końca 1944 r., gdy na teren prowincji niemieckiej wkroczyła Armia Czerwona. Jest to historia gwałtów, zniszczeń, zatopienia statków w Zalewie Wiślanym, migracji - wypędzenia, a także pogardy, przymusowej pracy, statusu „gorszych obywateli”

\footnotetext{
26 B. Anderson, Wspólnoty wyobrażone. Rozważania o źródłach i rozprzestrzenianiu się nacjonalizmu, Kraków 1997, s. 75.

27 B. Domagała, Mniejszość niemiecka i mniejszość ukrainska na Warmii i Mazurach. Dwa wzorce rozwiazywania problemów zwiazanych $z$ nauczaniem języka ojczystego, [w:] Ślazacy, Kaszubi, Mazurzy i Warmiacy - między polskościa a niemieckościa, red. A. Sakson, Poznań 2008, s. 356; B. Domagała, Mniejszość niemiecka na Warmii i Mazurach..., s. 126; 10 Jahre Deutsche Gesellschaften im Gebiet Ermland und Masuren. Eine Chronik..., s. 67; cf. [eka], Lekcja niemieckiego, „Mitteilungsblatt” nr 1(45), I 1999, s. 8; E. Kallenbach, Hänsel und Knödel. Lehrerseminar in Klein Strengeln vom 15-17 X 1999, „Mitteilungsblatt” nr 9(53), X 1999, s. 12; (lek), Olsztyn. Konferencja $w$ Urzędzie Wojewódzkim. Ważne rozmowy o języku, ibidem, nr 2/2015, s. 5.

28 Cf. np. opinie wyrażone w artykule L. Kryszałowicza, Wegój. Dzień Kultury Niemieckiej. Szkoła jakich mało..., „Mitteilungsblatt” nr 10/2009, s. 9. Niemniej należy zwrócić uwagę, iż pomimo tego że Niemcy w Polsce są mniejszością narodowa w największym stopniu korzystająca $z$ możliwości ustawowych wprowadzenia na terenie zwartych skupisk zamieszkiwania języka ojczystego jako pomocniczego i dodatkowych napisów urzędowych, na terenie Warmii i Mazur nigdzie nie wdrożono tych rozwiązań. Wynika to przede wszystkim $z$ małej koncentracji przestrzennej i niespełniania kryterium ilościowego. A. Bobryk, Usage of mother tongue by minorities in public life in Poland. The example of the German minority, [w:] The Fifth International Conference on History and Political Sciences. Proceedings of the Conference (January 23, 2015), red. K. Orzechowska, Vienna 2015, s. 61-62.
} 
i ograniczonych możliwości rozwoju zawodowego w PRL29. Stowarzyszenia mniejszości przypominają też życiorysy sławnych i ważnych osób zwiąanych $z$ regionem, jak chociażby postać Emila von Behringa, bakteriologa i laureata nagrody Nobla ${ }^{30}$, a także lokalne zwyczaje ludowe i żywieniowe - za przykład niech służy pierwsza zwrotka pieśni na cześć ziemniaka:

Alle Menschen, groß und kleine, leben nicht vom Brot alleine, auch Kartoffeln müssen sein, denn die schmecken immer fein ${ }^{31}$.

Utrwalanie tożsamości jest realizowane także przez praktyczne odświeżanie pamięci, czyli dbałość o zabytki architektury, pomniki historii np. cmentarze, tablice poległych $z$ I wojny światowej, które znajdowały się w poszczególnych powiatach dawnych Prus Wschodnich ${ }^{32}$. Sa to tylko pojedyncze przykłady budowania tożsamości narodowej poprzez zakorzenianie jej na nowo w pamięci, przy

29 Cf. np. Stanowisko Zarzadu Zwiazku Niemieckich Stowarzyszeń Społeczno-Kulturalnych $w$ Polsce, $z$ okazji 75 rocznicy zakończenia wojny, opublikowane 8 maja 2020 w Opolu, dostępne http://www.zsnwim.eu/pl/wydarzenia, (data dostępu: 18.11.2020); cf.: P. Sieger, Der letzte Akkord - Tragödie, „Mitteilungsblatt” nr 10/2014, s. 11-13; Gedenkfeier an die Opfer der drei Schiffe „Gustloff”,",Goya” und „Steuben” am 30. Januar 2008 in Gdingen, „Allensteiner Nachrichten” nr 2(52), 24 II 2008, s. 8; Alle vollen in Frieden leben, ibidem, nr 2(64), 24 II 2009, s. 1; Gdingen gedenkt der Opfer der Schifffahrtkatastrophen, ibidem, nr 2(70), 24 II 2010, s. 1.

30 Cf. biografię lekarza oraz informacje o tablicy pamiątkowej ufundowanej w Olsztynku: „Mitteilungsblatt” nr 4(19), IV 1996, s. 7; ibidem, nr 7(33), VII-VIII 1997, s. 7.

${ }^{31}$ Kartoffel-Lied, „Mitteilungsblatt” nr 10(302) 2020, s. 19; cf. też: R. Barczewski, Kartoffelfest im Hauskopernicus, „Allensteiner Nachrichten” nr 11 (73), 24 XII 2009, s. 8. Pierwsze „święto ziemniaka” w Domu Kopernika zorganizowano 10 XI 2009 i podtrzymywano w latach następnych, cf. np. Das II. Kartoffelfest in Allenstein, „Allensteiner Nachrichten” nr 8(82), 24 VIII 2010, s. 8.

32 Cf. np.: [Społeczny Komitet Ratowania Dawnych Cmentarzy na Warmii i Mazurach], „Masurische Storchenpost” nr 7, VII 1993, s. 19; L. Kryszałowicz, Wenn nicht wir - wer dann, „Mitteilungsblatt” nr 4(19), IV 1996, s. 7; Gedenktafel für Erzpriester Johann Hanowski, „Allensteiner Nachrichten” nr 2(4), 24 II 2004, s. 5; Andenken an den ersten Weltkrieg kehrt an seinen Platz zurück, „Allensteiner Nachrichten" nr 7-8 (57-58), 24 VIII 2008, s. 10. Należy zwrócić też uwage na płytę granitową poświęcona poległym w I wojnie światowej mieszkańcom Żabiego Rogu, po 1918 r., sygn. DH 4098 OMO oraz tablica $z$ nazwiskami poległych za ojczyznę podczas I wojny światowej, z okolic Barczewa, po 1918 r., sygn. DH 18277 OMO: zbiory Muzeum Warmii i Mazur w Olsztynie. 
pomocy relacji i wybranych elementów przeszłości, która w publicznej wersji, w poprzednich dziesięcioleciach, była pomijana lub równie wybiórczo traktowana. Całościowy proces kształtowania tożsamości poprzez pamięć Krzysztof Malicki określił następujacco: „pamięć zbiorowa jest także czynnikiem "wspomagającym" tożsamość w wymiarze społecznym przynajmniej na trzech poziomach: Po pierwsze, przez bycie tworzywem świadomości wspólnej przeszłości (im dłuższej tym lepszej, o czym świadczą pieczołowicie i z dużym zaangażowaniem obchodzone obrzędy i rocznice); po drugie jako przekaz wartości uosabianych przez pamiętane postacie lub wydarzenia (zawsze dobre lub zawsze złe, nigdy obojętne, gdyż w pamięci zbiorowej nie ma najczęśsiej miejsca na postaci niejednoznaczne); po trzecie, jako tworzywo symboli stających się dla grupy specyficznym "językiem"”3.

Przedstawione pokrótce relacje bezpośrednie, przywracanie znajomości języka niemieckiego, zakorzenianie w przeszłości i tradycji prowadzą do drugiego wybranego czynnika zabezpieczającego tożsamość, czyli do przynależności do grupy. Aktywność zabezpieczająca przynależność do grupy wyraża się w samej możliwości zapisania się do stowarzyszeń mniejszości niemieckiej oraz w ich faktycznej, obserwowalnej obecności w przestrzeni publicznej. Najważniejsze wydaje się to, że organizacje staraja się mieć własne siedziby, że kształtuja i podtrzymuja więzi $z$ organizacjami niemieckimi oraz że pośredniczą $\mathrm{w}$ kontaktach między organizacjami polskimi i niemieckimi. Własność lokalu ma nie tylko znaczenie ekonomiczne chociaż czynsze i wynajem moga pochłaniać znaczna część zasobów finansowych organizacji, to opłaty te czasowo umarzała lokalna administracja lub pokrywały je organizacje niemieckie ${ }^{34}$. Znacznie ważniejsza od finansów może być świadomość zakorzenienia, która tworzy się w sytuacji posiadania własnej siedziby. Wprawdzie na Warmii i Mazurach kilka stowarzyszeń wynajmuje pomieszczenia na swoja

\footnotetext{
${ }^{33} \mathrm{~K}$. Malicki, Regionalna tożsamość a pamięć zbiorowa. Przeszłość jako źródło więzi $z$ małymi ojczyznami, [w:] Kim jestem? Kim jesteśmy? Antropologiczne $i$ socjologiczne konteksty współczesnej tożsamości, red. D. Czakon i M. Boruta, przy współpracy R. Hołdy i R. Kantora, Kraków 2012, s. 271-272.

34 B. Domagała, Mniejszość niemiecka na Warmii i Mazurach..., s. 128-129. Zdarza się, że lokalne władze zwalniają stowarzyszenia $z$ konieczności płacenia czynszu w określonym okresie, cf. np.: Braunsberg. Neuer Sitz der Gesellschaft. Tapfer, stur und wirksam, „Mitteilungsblatt” nr 3(211), 2013, s. 4.
} 
działalność, jak chociażby stowarzyszenie w Olecku, w Olsztynku, Pasłęku, Piszu, Szczytnie, Węgorzewie. Ale inne mają własne miejsce. Olsztyńskie Stowarzyszenie Mniejszości Niemieckiej mieści się w kamienicy zwanej „Domem Kopernika” na ul. Partyzantów w Olsztynie. Została ona kupiona w tym celu w 1996 r. przez Zwiazek byłych Mieszkańców Olsztyna $z$ Gelsenkirchen (Kreisgemeinschaft Allenstein-Stadt) i wyremontowana przy pomocy środków innych organizacji ziomkowskich w Niemczech ${ }^{35}$. Stowarzyszenie Mniejszości Niemieckiej Narodowej „Mazury” w Ełku mieści się w zabytkowej wiè̇y ciśnień, zakupionej w 1994 r. dzięki funduszom Heinricha Westphala $z$ Hamburga. Do stowarzyszenia należą także budynki gospodarcze obok wieży36. W 2013 r. wieża ciśnień została poddana renowacji sfinansowanej przez Kreisgemeinschaft Lyck, Urząd Miasta Ełku i Związek Stowarzyszeń Niemieckich Warmii i Mazur ${ }^{37}$. Ostródzkie Stowarzyszenie Mniejszości Niemieckiej „Tannen” w 1994 r., kupiło dom od Urzędu Miasta w Ostródzie za pieniądze otrzymane od Kreisgemeinschaft Osterode. Otrzymał on nazwę stowarzyszenia - „Haus Tannen” i został wyremontowany przez członków lokalnej mniejszości niemieckiej38. Ze wsparcia organizacji ziomkowskiej skorzystało również Mragowskie Stowarzyszenie Ludności Niemieckiej „Niedźwiedzia Łapa”, które kupiło na potrzeby działalności „pomieszczenia biurowe”39. Z kolei stowarzyszenie w Kętrzynie otrzymało swoja siedzibę w 1997 r. od Ministerstwa Spraw Wewnętrznych RFN40.

35 (lek), Belohnte Gedult. Alle unter einem Dach, „Mitteilungsblatt” nr 3(18), III 1996, s. 1 i 2; Ze strychu do „Domu Kopernika” - 15 lat działalności Olsztyńskiego Stowarzyszenia Mniejszości Niemieckiej. Vom Dachgeschoss ins Haus Kopernikus 15-jährige Geschichte der Allensteiner Gesellschaft Deutscher Minderheit, opr. R. Barczewski, Olsztyn 2005, s. 4-8.

36 (lek), Der Turm eines Wunschbildes, „Mitteilungsblatt” nr 3(9), III 1995, s. 5-6.

37 (lek), Turm wie neu. Die Kur zeitigte einen sichtbaren Effekt, „Mitteilungsblatt” nr 10/2013, s. 5.

38 Eigenes Heim für die Gruppe „Tannen” in Osterode von Karl Moldaenke und Günter Behrendt, „Osteroder Rundbrief” nr 5 (29), V 1994; cf. też opis starań o własną siedzibę, http://smn-tannen.vdg.pl/index.php?strona=historia, (data dostępu: 18.11.2020).

39 Informacje o stowarzyszeniu mniejszości niemieckiej w Mragowie: https://www. zsnwim.eu/pl/organizacje/ 102-mragowo, (data dostępu: 18.11.2020).

40 „Mitteilungsblatt” nr 3(39), V-VII 1998, s. 4-5; cf. też historię działalności stowarzyszenia mniejszości niemieckiej w Kętrzynie: http://leksykonkultury.ceik.eu/ 
Własność siedziby ma symboliczne znaczenie „bycia u siebie”, szczególnie istotne po dziesięcioleciach życia, które cechowała tymczasowość. Andrzej Sakson wskazał, że dotyczyła ona prawie wszystkich aspektów życia na Warmii i Mazurach po 1945 r. Przywołał przykład tymczasowych dokumentów wręczanych ludności na tym terenie, czasowych zaświadczeń własności mieszkań i ziemi. Istotne było również poczucie destabilizacji codziennego życia, zwiazane z brakiem bezpieczeństwa fizycznego, ekonomicznego i społecznego ${ }^{41}$. Własność siedziby nie dość, że ułatwia działalność stowarzyszeń i czyni tańszym funkcjonowanie, to wzmacnia ich społeczne znaczenie i prawdopodobnie symbolicznie utrwala uprawnienia do działania ${ }^{42}$.

Siedziby stowarzyszeń mniejszości niemieckiej zostały zakupione głównie przez organizacje ziomkowskie, skupiające w Niemczech dawnych mieszkańców wschodniopruskich powiatów, osoby prywatne, wreszcie - przez rząd niemiecki. Pozwala to wnioskować, że współpraca $z$ Niemcami jest nie tylko niezbędna ekonomicznie, ale stanowi znaczne wsparcie w kształtowaniu poczucia przynależności do narodu i państwa niemieckiego. Realizuje się ona na dwóch płaszczyznach. Jedna tworza bezpośrednie kontakty członków danego stowarzyszenia $z$ organizacjami ziomkowskimi w Niemczech, a druga - pośredniczenie między polska administracja lokalną a organizacjami i instytucjami w Niemczech, które wymaga od członków stowarzyszeń zupełnie innych działań komunikacyjnych niż te, które wykonują we własnym gronie i w społeczności lokalnej.

Bezpośrednie kontakty stowarzyszeń $z$ organizacjami skupiającymi dawnych mieszkańców Prus Wschodnich to głównie spotkania, odwiedziny, szkolenia, seminaria. Oznaczało to wzajemne poznawanie się, było to także odnawianie starych znajomości, z tymi, którzy udali się do Niemiec podczas którejś fali wyjazdów. Na początku funkcjonowania stowarzyszeń szczególnie częste były

index.php/Stowarzyszenie_Mniejszo\%C5\%9Bci_Niemieckiej_w_K\%C4\%99trzynie, (data dostępu: 18.11.2020).

41 A. Sakson, Mazurzy..., s. 119-123.

42 Cf. np. W. Kiwak, Własność jako uprawnienie, „Studia Ekonomiczne. Zeszyty Naukowe Uniwersytetu Ekonomicznego w Katowicach” 2016, nr 260, s. 47-48. 
spotkania w centrum konferencyjnym Bad Pyrmont43. Poza szkoleniami i seminariami współpraca koncentrowała się na konkretnym potrzebach i celach, związanych $z$ kształceniem języka. Najczęstsze były kontakty $z$ Ziomkostwem Prus Wschodnich (Landsmannschaft Ostpreussen), najstarszym ziomkostwem w Niemczech, zawiazanym przez emigrantów z tej prowincji 3 października 1948 r., w Hamburgu. Obecnie struktury ziomkostw obejmuja organy centralne, zrzeszenia w ramach krajów związkowych Niemiec i oddziały terenowe ${ }^{44}$. Utworzone w 1950 r. Zrzeszenie Ziomkostw (Verband der Landsmannschaften - VdL), w 1957 r. zjednoczyło się ze Związkiem Wypędzonych Niemców (powstał w 1951 r.), tworzac Zwiazek Wypędzonych (Bund der Vertriebenen, Vereinigte Landsmannschaften und Landesverbände $-\mathrm{BdV})^{45}$.

W miarę upływu czasu bezpośrednie kontakty stowarzyszeń $z$ organizacjami niemieckimi zmieniały się - pojawiały się nowe potrzeby, jak finansowanie rozmaitych inicjatyw, wymagajacych zdobywania niemieckich środków publicznych. Zmieniały się style odwiedzin, uwarunkowanych znajomościa języka, wiekiem członków organizacji i w Polsce, i w Niemczech. $Z$ czasem zanikło pośrednictwo, które można określić jako „łącznikowe” - stowarzyszenia nie umieszczaja już na łamach swoich czasopism ogłoszeń o zaginionych podczas wojny osobach ${ }^{46}$, a także ogłoszeń matrymonialnych ${ }^{47}$.

43 A. Borchert, Schon 20 deutsche Vereine gegründet. 42 Vertreter aus der Heimat auf LO-Arbeitstagung in Bad Pyrmont, "Masurische Storchenpost” nr 1, I 1992, s. 22-23; (V), Ein gelungenes Seminar in Bad Pyrmont, „Mitteilungsblatt” nr 4(10) IV 1995, s. 3 i 5.

44 K. Żygulski, Przesiedleńcy w NRF, [w:] Niemiecka Republika Federalna, red. K. M. Pospieszalski i J. Ziółkowski, Poznań 1965, s. 294.

45 Ibidem, s. 292-293; B. Ociepka, Zwiazek Wypędzonych, [w:] Wspólne dziedzictwo? Ze studiów nad stosunkiem do spuścizny kulturowej na Ziemiach Zachodnich i Pótnocnych, red. Z. Mazur, Poznań 2000, s. 828-830; cf. historia powstania organizacji: http://www.bund-der-vertriebenen.de/, (data dostępu: 18.11.2020).

46 Cf. np.: ogłoszenie ze zdjęciem poszukiwanego Hansa Weynella, ur. 26 XI 1926 r. w Labiau (dzisiaj Polessk, Okręg Kaliningradzki). Rolę skrzynki kontaktowej pełniła przewodnicząca stowarzyszenia z Olecka: „Mitteilungsblatt” nr 7(13), VIII-IX 1999, s. 8.

47 Cf. ogłoszenie: Bodo Symanski, $1.71 \mathrm{~m}$, ważący $75 \mathrm{~kg}$, „gut situiert, zuverlässig, naturliebend, reisefreundig, aufgeschlossen, musikliebend, humorvoll” pozna "natürlich, warmherzig, hausfraulich, schlank, solide, anhanglos” kobietę do 42 lat, 1.7 m, która waży $57 \mathrm{~kg}$ i zna język niemiecki: „Mitteilungsblatt” nr 1(13), I 1993. 
Wytworzyły się takie formy organizacyjne jak Centrum Informacji Gospodarczych, Społecznych i Kulturalnych, istniejacce przy OSMN od 2003 r. Jego celem stało się ułatwianie kontaktów między polskimi i niemieckimi przedsiębiorcami i podmiotami gospodarczymi48. Od początku funkcjonowania stowarzyszenia mniejszości niemieckiej mogły korzystać z państwowych dotacji, zarówno w Polsce, jak i w Niemczech. Budżet państwa niemieckiego przewidywał wysokie sumy na takie wsparcie do chwili wejścia Polski do Unii Europejskiej. Od tego czasu stowarzyszenia mniejszości niemieckiej przede wszystkim mogą się starać o sfinansowanie swoich aktywności bezpośrednio w instytucjach unijnych oraz za pomoca lokalnej administracji państwowej i samorządowej" ${ }^{49}$.

Stowarzyszenia pośredniczą $\mathrm{w}$ kontaktach między miastami i gminami, które prowadzą do podpisania umów partnerskich ${ }^{50}$. Ta forma współpracy jest swoistą kontynuacją patronatów, jakimi miasta w Niemczech obejmowały wysiedlona po 1945 r. ludność wschodniopruską ${ }^{51}$. Umowy partnerskie mają zwykle ułatwiać kontakty gospodarcze, umożliwiają wymianę młodzieży, przedstawicieli różnych zawodów, szkolenia. $Z$ obserwacji wynika, że funkcja pośrednicząca stowarzyszeń mniejszości często kończy się w momencie podpisania takiego dokumentu.

48 Cf. S. Damaschke, Rede zur Unterzeichnung der Partnerschaftsurkunde mit der polnischen Stadt Mragowo ehem. Sensburg in Mragowo am 6.6.1993, „Masurische Storchenpost" nr 7/1993, s. 28; J. Felis, Zentrum für wirtschaftliche Informationen, „Allensteiner Nachrichten” nr 1/2003, s. 3; Ze strychu do „Domu Kopernika”..., s. 24. 49 (lek), Olsztyn. Walne zebranie Zwiazku Stowarzyszeñ Niemieckich. Mniej pieniędzy i mniej członków, „Mitteilungsblatt” nr 5/2008, s. 5.

50 Oficjalne umowy partnerskie między miastami i gminami Polski i RFN były zawierane w latach 70 . XX w., po podpisaniu Układu o normalizacji wzajemnych stosunków 7 XII 1970 r. Jednak najwięcej umów zawarto po wejściu w życie ustawy o samorządzie terytorialnym z 28 III 1990 r., która uzupełniła ustawa o terenowych organach rządowej administracji ogólnej z 8 VIII 1996 r. Miasta, powiaty i gminy Warmii i Mazur podpisują umowy partnerskie $z$ ośrodkami we Francji, Holandii, Portugalii, Irlandii, Czechach, Anglii, Szwecji, na Litwie, Ukrainie, Białorusi, Łotwie i innymi: A. Trzcielińska-Polus, Polsko-niemiecka współpraca regionalna i lokalna, [w:] Polacy i Niemcy na drodze do partnerskiego sasiedztwa. Próba bilansu dziesięciolecia 1989-1998, red. D. Bingen, K. Malinowski, Poznań 2000, s. 349-354.

51 Patronaty miast zapoczątkowała pomoc udzielana Prusom Wschodnim w czasie I wojny światowej. B. Ociepka, Dziedzictwo wypędzonych, [w:] Wspólne dziedzictwo? Ze studiów nad stosunkiem do spuścizny kulturowej na Ziemiach Zachodnich i Pólnocnych, red. Z. Mazur, Poznań 2000, s. 732-733; A. Kossert, Tradycje „stron ojczystych" w RFN. Fenomen Prus Wschodnich, [w:] ibidem, s. 772. 


\section{Zabezpieczenie $w$ codzienności}

Aktywności zabezpieczające przynależność członków stowarzyszeń są związane $z$ kształtowaniem tej części tożsamości, która dotyczy wspólnotowych i podzielanych działań, przestrzeni oraz ma oparcie w instytucjach działajacych w państwie niemieckim. Dopełnieniem zabezpieczeń tożsamości w tym względzie jest także bezpieczeństwo materialne - socjalne, szczególnie istotne w sytuacji społeczno-gospodarczej Warmii i Mazur, które między innymi cechuje wyższe niż w innych częściach Polski bezrobocie, powolny odpływ bardziej aktywnych i lepiej wykształconych jednostek, a także spirala nędzy dotykająca mieszkańców regionu ${ }^{52}$.

Aktywności zabezpieczające byt były szczególnie ważna częścią działań stowarzyszeń mniejszości niemieckiej na samym początku ich funkcjonowania, które zbiegło się ze zmianami ustrojowymi przełomu lat osiemdziesiatych i dziewięćdziesiątych XX w. Niezbędnym dopełnieniem charakterystyki tej sfery aktywności stowarzyszeń jest opis stanu infrastruktury miejskiej i wiejskiej tego regionu z końca wojny. Podczas działań wojennych w 1944 i 1945 r. doznała ona poważnych zniszczeń, a niemal całkowita wymiana ludności, powojenna bieda i ustrój polityczny w następnych latach nie sprzyjały jej odtwarzaniu i rozbudowywaniu. Ponadto była to niemiecka infrastruktura, a nowi osiedleńcy doświadczyli w czasie II wojny światowej niemieckiej okupacji i nie mieli wielu powodów, by rekonstruować stan sprzed zniszczeń. Jest to uproszczony opis sytuacji, jednak jego celem jest naświetlenie położenia tej części ludności miejscowej, która zdecydowała się żyć w powojennej Polsce. Radykalnie przeobraził się otaczający ich świat - zniknęły nazwy miejscowe, całkiem zmieniło się uwarstwienie społeczne, zniknęły części trwałych - architektonicznych - elementów przestrzeni publicznej. W hierarchii społecznej ludność miejscowa znajdowała się najczęściej w niższych warstwach - na niekorzyść działała słaba znajomość języka polskiego, na ogół niewysokie wykształcenie czy też fach niezbyt przydatny w nowych warunkach ustrojowych (np. rzemieślniczy).

52 Cf. W. Dziemianowicz, A. Laskowska, Warmia i Mazury - innowacje wokół strategicznych zasobów naturalnych, „Studia Komitetu Przestrzennego Zagospodarowania Kraju" 2017, nr 179, s. 30. 
Ten stan zmieniał się w miarę upływu lat, niemniej w okresie przełomu ustrojowego lat 80. i 90. XX w. ogólna sytuacja materialna mieszkańców Warmii i Mazur nie była najlepsza. Dodatkowo, potencjalni członkowie stowarzyszeń mniejszości nie byli już młodymi ludźmi. Dlatego szczególnie w początkowym okresie swojego istnienia stowarzyszenia mniejszości niemieckiej starały się zapewniać swoim członkom doraźne wsparcie materialne, a także możliwości dokształcania i znalezienia pracy w Niemczech53. Możliwość zatrudnienia w Niemczech była szczególnie ważna przed wstapieniem Polski do Unii Europejskiej, zwłaszcza że część członków stowarzyszeń postarała się o podwójne paszporty ${ }^{54}$. Stowarzyszenia pomagały reklamować informacje o gospodarstwach agroturystycznych prowadzonych przez swoich członków ${ }^{55}$, zamieszczały również reklamy produktów spożywczych lub firm ${ }^{56}$.

Oferowane przez stowarzyszenia zabezpieczenie bytu obejmowało również prywatne darowizny składane przy różnych okazjach przez pojedynczych członków organizacji ziomkowskich ${ }^{57}$. Wspomniane już zjazdy seniorów były organizowane tak, by zapewnić uczestnikom bezpłatny transport i wyżywienie. Stowarzyszenia

53 Hilfe für Arbeitslose, „Mitteilungsblatt nr 3/4, 15 X 1994; (lek), Ich achnte, daß es hier Deutsche gibt, ibidem, nr 2(8) 1995, s. 1 i 4; (hh), „Tannen” im Harz, ibidem, nr 10/2013, s. 11; Deutsche Jugend aus Ostpreußen hofft auf Praktikumsplätze in der Bundesrepublik, „Allensteiner Nachrichten” nr 6(8), 26 VI 2004, s. 1; ogłoszenie o "stałej, licencjonowanej linii Polska-Niemcy-Polska”, ibidem, nr 6(56), 24 VI 2008, s. 8; Die Johanniter, ibidem, nr 4(66), 24 IV 2009, s. 2; Zerspanungsmechaniker gefragt - kostenlose Ausbildung in Deutschland, ibidem, nr 3(77), 24 III 2010, s. 6.

54 L. Kryszałowicz, O dwóch paszportach, „Mitteilungsblatt” nr 9(24), IX 1996, s. 9; cf. też ofertę pracy w Niemczech $z$ następująca informacją: „Warunek: paszport lub staat. Zakwaterowanie bezpłatne”: ibidem, nr 7(51), VII 1999, s. 14.

55 Urlaub auf dem Bauernhof - eine Chance für Bauern, „Mitteilungsblatt” nr 5(11), V 1995 s. 2; [Agroturystyka proponowana przez Ermländisch-Masurischer Verband deutschstämmiger Landfrauen in Allenstein], ibidem, nr 5, V 1997, s. 4; T. Budnikowski, Wymiana turystyczna między Polska a Niemcami, [w]: Polacy i Niemcy na drodze do partnerskiego sasiedztwa. Próba bilansu dziesięciolecia 1989-1998, red. D. Bingen i K. Malinowski, Poznań 2000, s. 239.

56 Cf. reklama firmy produkujacej przyprawy: „Osteroder Rundbrief” $\mathrm{nr}$ 1(25), I 1994.

57 Cf. podziękowania za dary pieniężne i paczki dla dzieci, skierowane do osób prywatnych w Niemczech: „Osteroder Rundbrief” nr 7(19), VII 1993; ibidem, nr 8(20), VIII 1993. Cf. podziękowania za dary w okresie świąt Bożego Narodzenia: „Mitteilungsblatt“ nr 8(44), XII 1998, s. 9; Cf. też historię Georga Dietricha, który przez wiele lat wspierał mieszkańców Olsztyna, ibidem, nr 2(28), II 1997, s. 1. 
pośredniczyły także $\mathrm{w}$ rozdzielaniu $\mathrm{w}$ swoim środowisku lokalnym darów materialnych (żywność, odzież, sprzęty biurowe i domowe, zabawki etc.), które napływały $z$ Niemiec w latach 90. XX w. 58

\section{Podsumowanie}

$\mathrm{Na}$ koniec warto przywołać diagnozę, którą w 2012 r. Jacek Leoński sformułował na temat tożsamości regionalnej mieszkańców Ziem Zachodnich i Północnych, a więc także Warmii i Mazur: „zarówno poprzednie kilkadziesiąt lat (brak czynników sprzyjających tworzeniu się więzi integracyjnych), jak i sytuacja obecna (wejście Polski do Unii Europejskiej oraz procesy globalizacyjne) nie sprzyjały i nie będa sprzyjać tworzeniu się świadomości regionalnej na Ziemiach Zachodnich. Zatem można powiedzieć, że mamy tu do czynienia ze społeczeństwem regionalnym bez historii i bez nadziei na historię"59. Jak się wydaje, twierdzenie o bezpiecznej tożsamości znajduje swoje miejsce w tej bardzo radykalnej ocenie. Stanowi ona poniekąd rezultat życia w regionie, w którym ciagłość trwania społecznego, przestrzeń regionu, lokalne więzi społeczne tak często były i sa przecinane.

Bezpieczna tożsamość ma dwa wymiary - jest bezpieczna, gdyż nie powoduje u jej posiadaczy konfliktów wewnętrznych, pozwala na wspólistnienie elementów kultury, które mają źródła w rozmaitych więziach i wymiarach społecznych. Taka tożsamość nie powoduje wielu sporów w wymiarze zewnętrznym, w którym cechy tej tożsamości sa prezentowane $\mathrm{w}$ rozmaitych środowiskach kulturowych. W sumie jest to tożsamość niekonfrontacyjna, co być może lepiej definiuje jej cechy w świetle wyżej przedstawionych wywodów. Bezpieczna - niekonfrontacyjna tożsamość, realizowana w relacjach bezpośrednich, polega na:

1) regularnych spotkaniach $\mathrm{w}$ gronie ludzi o podobnych doświadczeniach $z$ przeszłości, podobnej tęsknocie za utraconym

58 (lek), Wartenburg. Herz und alle für geleistete Hilfe. Sie wollten etwas Nützliches machen „Mitteilungsblatt” nr 9/2008, s. 14; Oppeln. Vorstandsmitglieder wurden gewählt Gaida anstatt Płocharska, ibidem, nr 6/2014, s. 13.

59 Za: Z. Kurcz, Ż. Stasieniuk, Wstęp, [w:] Od Polonii po Ziemie Zachodnie. Pamięci Profesora Jacka Leońskiego, red. Z. Kurcz, Ż. Stasieniuk, Szczecin 2014, s. 10. 
w dzieciństwie językiem, nazwami lokalnymi, zwyczajami i „porządkiem rzeczy” w życiu codziennym;

2) wspomnieniach przeszłości, głównie martyrologii końca wojny i doświadczeń życia w pierwszych latach po jej zakończeniu;

3) kształtowaniu przekonań, że w razie problemów materialnych człowiek nie pozostanie osamotniony.

Zabezpieczenie tożsamości kulturowej obejmuje zasadniczo język, zwyczaje, wybrane elementy historii, polega na utrzymywaniu kontaktów $z$ państwem niemieckim i niemieckimi organizacjami. Wszystkie te działania nie maja radykalnego, jednoznacznego charakteru etnicznego, sa przeprowadzane w postaci ciagłego dialogu, uzgadniania znaczeń kulturowych, historycznych, narodowych, wybierania tego, co nie wywoła większych konfliktów. Jak długo taka tożsamość będzie wystarczać - zabezpieczać przynależność, zakorzenienie, zaufanie, wolę działania na przyszłość?

\section{Bibliografia / References}

Monografie/monographs

Anderson B., Wspólnoty wyobrażone. Rozważania o źródłach i rozprzestrzenianiu się nacjonalizmu, Kraków 1997.

Domagała B., Mniejszość niemiecka na Warmii i Mazurach. Rodowód kulturowy, organizacja, tożsamość, Olsztyn 1996.

Gałęziowska M., Tożsamość organizacyjna mniejszości niemieckiej na Warmii i Mazurach, Olsztyn 2017.

Król E.C., Polska i Polacy $w$ propagandzie narodowego socjalizmu w Niemczech 1919-1945, Warszawa 2006.

Madajczyk P., Niemcy polscy 1944-1989, Warszawa 2001.

Sakson A., Mazurzy - społeczność pogranicza, Poznań 1990.

Sakson A., Stosunki narodowościowe na Warmii i Mazurach 1945-1997, Poznań 1998.

\section{Artykuły/articles}

Bobryk A., Attitudes towards the Mother Tongue as an Identity Manifestation of National and Ethnic Minorities in Poland, [w:] Identities of Central-Eastern European Nations, red. V. Yevtukh, A. Wysocki, G. Kisla, A. Jekaterynczuk, Kyiv 2016.

Bobryk A., Kalita C., Policy and the national minorities in Poland. Social and philosophical aspect, „Austrian Journal of Humanities and Social Sciences" 2015, nr 11-12. 
Bobryk A., Usage of mother tongue by minorities in public life in Poland. The example of the German minority, [w:] The Fifth International Conference on History and Political Sciences. Proceedings of the Conference (January 23, 2015), red. K. Orzechowska, Vienna 2015.

Budnikowski T., Wymiana turystyczna między Polska a Niemcami, [w:] Polacy i Niemcy na drodze do partnerskiego sasiedztwa. Próba bilansu dziesiecciolecia 1989-1998, red. D. Bingen i K. Malinowski, Poznań 2000.

Domagała B., Mniejszość niemiecka i mniejszość ukraińska na Warmii i Mazurach. Dwa wzorce rozwiazywania problemów zwiazanych z nauczaniem języka ojczystego, [w:] Ślazacy, Kaszubi, Mazurzy $i$ Warmiacy - między polskościa a niemieckościa, red. A. Sakson, Poznań 2008.

Dziemianowicz W., Laskowska A., Warmia i Mazury - innowacje wokót strategicznych zasobów naturalnych, „Studia Komitetu Przestrzennego Zagospodarowania Kraju" 2017, nr 179.

Gawkowska A., Aktywne społeczeństwo a komunitaryzm według Amitaia Etzioniego, [w:] A. Etzioni, Aktywne spoleczeństwo. Teoria procesów spolecznych i politycznych, przeł. S. Burdziej, Kraków 2012.

Golka M., Czy istnieje wielokulturowość tożsamości?, [w:] Kim jestem? Kim jesteśmy? Antropologiczne $i$ socjologiczne konteksty współczesnej tożsamości, red. D. Czakon i M. Boruta, przy współpracy R. Hołdy i R. Kantora, Kraków 2012.

Kiwak W., Własność jako uprawnienie, „Studia Ekonomiczne. Zeszyty Naukowe Uniwersytetu Ekonomicznego w Katowicach" 2016, nr 260.

Kossert A., Tradycje „stron ojczystych" w RFN. Fenomen Prus Wschodnich, [w:] Wspólne dziedzictwo? Ze studiów nad stosunkiem do spuscizny kulturowej na Ziemiach Zachodnich i Północnych, red. Z. Mazur, Poznań 2000.

Kurcz Z., Stasieniuk Ż., Wstęp, [w:] Od Polonii po Ziemie Zachodnie. Pamięci Profesora Jacka Leońskiego, red. Z. Kurcz, Ż. Stasieniuk, Szczecin 2014.

Malicki K., Regionalna tożsamość a pamięć zbiorowa. Przeszłość jako źródło więzi z małymi ojczyznami, [w:] Kim jestem? Kim jesteśmy? Antropologiczne $i$ socjologiczne konteksty współczesnej tożsamości, red. D. Czakon i M. Boruta, przy współpracy R. Hołdy i R. Kantora, Kraków 2012.

Mamzer H., Poczucie bezpieczeństwa ontologicznego. Uwarunkowania społeczno-kulturowe, „Seria Socjologia”, nr 58, Poznań 2008.

Ociepka B., Dziedzictwo wypędzonych, [w:] Wspólne dziedzictwo? Ze studiów nad stosunkiem do spuścizny kulturowej na Ziemiach Zachodnich i Pótnocnych, red. Z. Mazur, Poznań 2000. 
Ociepka B., Zwiazek Wypędzonych, [w:] Wspólne dziedzictwo? Ze studiów nad stosunkiem do spuścizny kulturowej na Ziemiach Zachodnich i Północnych, red. Z. Mazur, Poznań 2000.

Sakson A., Rola mniejszości niemieckiej $w$ stosunkach polsko-niemieckich na przykładzie Warmii i Mazur, „Przegląd Zachodni” 1998, z. 11 .

Sakson A., Mazurzy - dylematy tożsamości, „Rocznik Ziem Zachodnich”, $01 / 2017$.

Trzcielińska-Polus A., Polsko-niemiecka współpraca regionalna i lokalna, [w:] Polacy i Niemcy na drodze do partnerskiego sasiedztwa. Próba bilansu dziesięciolecia 1989-1998, red. D. Bingen, K. Malinowski, Poznań 2000.

Żygulski K., Przesiedleńcy w NRF, [w:] Niemiecka Republika Federalna, red. K.M. Pospieszalski i J. Ziółkowski, Poznań 1965.

Strony internetowe/websites

https://www.zsnwim.eu/pl/ wykaz organizacji należących i nienależących do ZSNWiM, (data dostępu: 17.11.2020).

https://www.agdm.pl/de/aktuelles-von-der-agdm/aenderung-der-deutschsprachigen-gottesdienstzeiten/, (data dostępu: 18.11.2020).

https://www.zsnwim.eu/pl/miesiecznik, (data dostępu: 17.11.2020).

https://www.agdm.pl/projekty/allensteiner-nachrichten/, (data dostępu: 17.11.2020).

https://www.zsnwim.eu/pl/wydarzenia, (data dostępu: 18.11.2020).

http://smn-tannen.vdg.pl/index.php?strona=historia, (data dostępu: 18.11.2020).

https://www.zsnwim.eu/pl/organizacje/102-mragowo, (data dostępu: 18.11.2020).

http://leksykonkultury.ceik.eu/index.php/Stowarzyszenie_Mniejszo \%C5\%9Bci_Niemieckiej_w_K\%C4\%99trzynie, (data dostępu: 18.11.2020).

http://www.bund-der-vertriebenen.de/, (data dostępu: 18.11.2020).

Źródła drukowane/published sources

„Allensteiner Nachrichten” 2003, 2004, 2008, 2009, 2010, 2012.

„Masurische Storchenpost” 1992, 1993.

„Mitteilungsblatt” 1993, 1994, 1995, 1996, 1997, 1998, 1999, 2009, 2013, 2014, 2015, 2020.

„Osteroder Rundbrief” 1992, 1993, 1994.

„Wiadomości Mazurskie” 1946.

"Życie Olsztyńskie” 1948.

„Gazeta Olsztyńska” 18 IX 2000. 
10 Jahre Deutsche Gesellschaften im Gebiet Ermland und Masuren. Eine Chronik, Verband der deutschen Gesellschaften im ehem. Ostpreußen, Text und Zusammenstellung Elisabeth Kallenbach, Allenstein 2000.

Ze strychu do „Domu Kopernika” - 15 lat działalności Olsztyńskiego Stowarzyszenia Mniejszości Niemieckiej. Vom Dachgeschoss ins Haus Kopernikus - 15-jährige Geschichte der Allensteiner Gesellschaft Deutscher Minderheit, oprac. R. Barczewski, Olsztyn 2005. 